\title{
Laser-assisted lipolysis for arm contouring in Teimourian grades III and IV: A prospective study involving 22 patients
}

\author{
Franck Marie Leclère $M D P h D^{1,2,3}$, Justo $M$ Alcolea $M D^{4}$, Peter $M$ Vogt MD PhD ${ }^{3}$, Javier Moreno-Moraga $M D^{5}$, \\ Vincent Casoli MD PhD ${ }^{1}$, Serge Mordon $\mathrm{PhD}^{2}$, Mario A Trelles MD PhD ${ }^{4}$
}

\begin{abstract}
FM Leclère, JM Alcolea, PM Vogt, et al. Laserassisted lipolysis for arm contouring in Teimourian grades III and IV: A prospective study involving 22 patients. Plast Surg 2016;24(1):35-40.
\end{abstract}

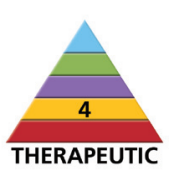

BACKGROUND: Upper arm deformities secondary to weight loss or senile elastosis have led to an increased demand for aesthetic contouring procedures. OBJECTIVE: To objectively assess whether, in Teimourian high-grade upper arm remodelling, laser-assisted lypolysis (LAL) alone could result in patient satisfaction.

METHODS: Between 2012 and 2013, 22 patients were treated for excessive upper arm fat (Teimourian grade III and IV) solely with LAL. The laser used in the present study was a $1470 \mathrm{~nm}$ diode laser (Alma Lasers, Israel) with the following parameters: continuous mode, $15 \mathrm{~W}$ power and transmission through a $600 \mu \mathrm{m}$ optical fibre. Previous mathematical modelling suggested that $0.1 \mathrm{~kJ}$ was required to destroy $1 \mathrm{~mL}$ of fat. Patients were asked to complete a satisfaction questionnaire. The arm circumference was measured pre- and postoperatively. Treatment parameters, adverse effects and outcomes were recorded.

RESULTS: Pain during the anesthesia and discomfort after the procedure were minimal. Complications included ecchymoses and prolonged edema. The mean $( \pm$ SD) arm circumference decreased $5.5 \pm 1.0 \mathrm{~cm}$ in the right $\operatorname{arm}(\mathrm{P}<0.01)$ and $5.2 \pm 1.1 \mathrm{~cm}$ in the left arm $(\mathrm{P}<0.01)$ in grade III patients and $4.9 \pm 1.1 \mathrm{~cm}$ in the right arm $(\mathrm{P}<0.01)$ and $4.9 \pm 1.1 \mathrm{~cm}$ in the left arm $(\mathrm{P}<0.01)$ in grade IV patients. Although the circumference of both arms significantly decreased in grade III and grade IV patients, the skin tightening remained incomplete. Overall, the average opinion of treatment was poor for both patients and investigators. Of the 22 patients, only nine $(41 \%)$ would recommend this treatment.

CONCLUSION: LAL for upper arm remodelling is not sufficient to ensure full skin tightening for patients with Teimourian grades III and IV upper arm deformities. A complementary surgery is mandatory for grades III and IV.

Key Words: Arm; Arm remodelling; Brachioplasty; LAL; Laser; Laser lipolysis

\section{Lipolyse laser pour le remodelage des déformations des bras de grades Teimourian III et IV : Etude prospective à propos de 22 patients}

ETAT DE L'ART: Les déformations des bras attribuables à une perte de poids ou à l'élastose sénile ont suscité l'augmentation des demandes d'interventions de redrapage esthétique.

OBJECTIF: Evaluer objectivement si la lipolyse laser (LL) seule, utilisée pour le redrapage des bras de grades Teimourian III et IV, permet la satisfaction des patients

MATÉRIEL ET MÉTHODES: Entre 2012 et 2013, 22 patients ont été traités par LL seule pour le redrapage des bras de grades Teimourian III et IV. Le laser diode $1470 \mathrm{~nm}$ (Alma Lasers, Israël) était utilisé avec les paramètres suivants : mode continu, puissance de $15 \mathrm{~W}$, et transmission par fibre optique de $600 \mu \mathrm{m}$. Selon notre modélisation antérieure, 0,1 kJ était nécessaire pour détruire $1 \mathrm{~mL}$ de tissus adipeux. Les patients ont été invités à remplir un questionnaire de satisfaction. La circonférence des bras étaient consignée avant et après intervention. Les paramètres laser requis, les complications, et les résultats étaient enregistrés de manière prospective.

RÉSULTATS: La douleur pendant l'anesthésie et l'inconfort après l'intervention étaient minimes avec cette technique. Les complications incluaient des ecchymoses et un œdème prolongé. La circonférence moyenne des bras a diminué de $5,5 \pm 1,0 \mathrm{~cm}$ au bras droit $(\mathrm{p}<0,01)$ et $5,2 \pm 1,1 \mathrm{~cm}$ au bras gauche $(p<0,01)$ chez les patients de grade Teimourian III, et de $4,9 \pm 1,1 \mathrm{~cm}$ au bras droit $(\mathrm{p}<0,01)$ et $4,9 \pm 1,1 \mathrm{~cm}$ au bras gauche $(\mathrm{p}<0,01)$ chez les patients de grade IV. Même si la circonférence des deux bras a diminué considérablement pour les grades Teimourian III et IV, le redrapage cutané est demeuré incomplet. En moyenne, le résultat est jugé insatisfaisant tant pour les patients que pour les investigateurs. Sur les 22 patients, seuls neuf (41\%) recommanderaient le traitement.

CONCLUSION: La lipolyse laser est insuffisante pour assurer un redrapage complet des déformations des bras de grades Teimourian III et IV. Une chirurgie complémentaire reste nécessaire dans ces cas-là.
U pper arm deformities secondary to weight loss or senile elastosis have led to an increased demand for aesthetic contouring procedures. Traditional approaches to treat this condition included liposuction and, in severe cases, brachioplasty with resection of excess tissue. The main side effects related to arm lift are seroma, hypertrophic scarring, cellulitis, wound dehiscence, subcutaneous abscess, nerve injury and irregularities (1-3). Liposuction is effective in some cases; however, there has been no evidence that the procedure improves skin laxity. Additionally, this technique has the following limitations: increased blood loss; ecchymoses; long recovery times; increased postoperative discomfort; potential for pulmonary emboli; and seromas $(4,5)$. The search for and development of new liposuction technologies and techniques has grown steadily over the past decades to keep pace with patients' requirements and expectations for greater efficacy and safety. Recent decades have witnessed the introduction of internal ultrasound-assisted liposuction, power-assisted liposuction and laser-assisted lypolysis (LAL) $(6,7)$.

Since 2004, and using our mathematical model, we have been working toward developing a safe technique for LAL (8). Based on the literature and our previous observations (9-16), LAL is a reliable technique for low- to medium-grade upper arm remodelling because of the following: the lipolysis effect improves and facilitates the removal of adipose tissue; the disruption and coagulation of collagen may lead to the creation of a new, thicker and more organized reticular dermis with the end

\footnotetext{
${ }^{1}$ Department of Plastic $\mathcal{G}$ Transsexual Surgery, Burn Surgery, Hand Surgery, CHU University of Bordeaux, Centre François-Xavier-Michelet, Groupe hospitalier Pellegrin, Bordeaux; ${ }^{2}$ INSERM U1189, University of Lille, France; ${ }^{3}$ Department of Plastic Surgery, Hannover Medical School, University of Hannover, Germany; ${ }^{4}$ Instituto Médico Vilafortuny, Cambrils (Tarragona); ${ }^{5}$ Instituto Médico Láser, Madrid, Spain Correspondence: Dr. Franck Marie Leclère, INSERM U1189 ONCO-THAI, Université Lille 2 Droit et Santé, 1 Avenue Oscar Lambret, 59037 Lille Cedex. Telephone 33-0-6-60887762, fax 33-0-3-20446708, e-mail franck.leclere@inserm.fr, franckleclere@yahoo.fr
} 
TABLE 1

Teimourian classification and usual recommended treatment

\begin{tabular}{|c|c|c|}
\hline Stage & Clinical appearance & Recommended treatment \\
\hline 1 & Minimal fat $<250 \mathrm{~mL}$, no ptosis & Circumferential liposuction \\
\hline $2 a$ & $\begin{array}{l}\text { Moderate fat, grade } 1 \text { ptosis } \\
<5 \mathrm{~cm}\end{array}$ & Liposuction in two sessions \\
\hline $2 b$ & $\begin{array}{l}\text { Moderate to severe fat, grade } 2 \\
\text { ptosis, } 5 \mathrm{~cm} \text { to } 10 \mathrm{~cm}\end{array}$ & $\begin{array}{c}\text { Distal liposuction + proximal } \\
\text { short-scar brachioplasty }\end{array}$ \\
\hline 3 & $\begin{array}{l}\text { Extreme lipodystrophy with grade } 3 \\
\text { ptosis }>10 \mathrm{~cm}\end{array}$ & Liposuction + brachioplasty \\
\hline 4 & $\begin{array}{l}\text { Mild to moderate fat with severe } \\
\text { grade } 3 \text { ptosis }\end{array}$ & Traditional brachioplasty \\
\hline
\end{tabular}

Adapted from references 1 and 19

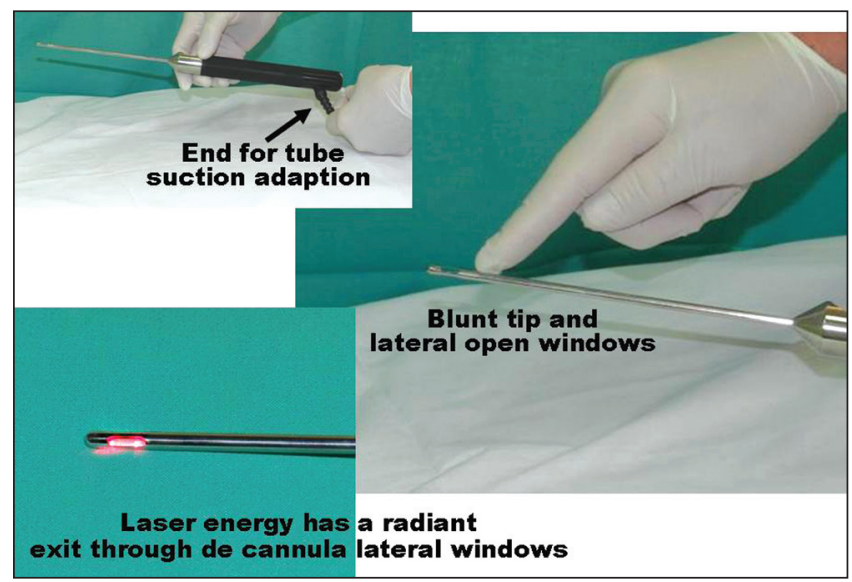

Figure 1) Laser cannula used in the present study

clinical results being tightened skin and reduced laxity; due to the small cannula size, mechanical destruction is kept to a minimum, resulting in faster recovery times and a lower incidence of ecchymoses; coagulation of small vessels reduces procedural trauma; and the easy penetration of the cannula with the laser fibre in the fibrous tissue makes it easier to reach all of the areas with the help of the external hand, contributing to high patient satisfaction.

After excellent outcomes in low- to medium-grade upper arm remodelling but controversial results in Teimourian high-grade upper arm remodelling, we conducted the present study to assess whether LAL alone could lead to patient satisfaction in case of high skin ptosis. Herein, we classify the ptosis and dystrophy and compare our results with the current literature.

\section{METHODS}

Patients

The present clinical study protocol was reviewed and approved by the local ethics committee. Twenty-two patients who were dissatisfied with the appearance of their upper arms and classified as Teimourian grade III (group TIII) (13 patients) or Teimourian grade IV (group TIV) (nine patients), according to the Teimourian and Malekzadeh classification (1) (Table 1), were recruited for the present study. Exclusion criteria were the following: pregnancy, history of coagulation disorders or anticoagulants, history of allergy to the active ingredients or excipients of the anesthetics used, and history of sensitivity to laser treatment or intense pulsed light therapy. Mean $( \pm$ SD) patient age was $45.3 \pm 10.2$ years (range 25 to 61 years) and mean body mass index was $25.8 \pm 1.4 \mathrm{~kg} / \mathrm{m}^{2}$ (range $23.6 \mathrm{~kg} / \mathrm{m}^{2}$ to $28.4 \mathrm{~kg} / \mathrm{m}^{2}$ ) (Table 2).

Laser and dosimetry

The laser used in the present study was a $1470 \mathrm{~nm}$ diode laser (Alma Lasers, Israel). Laser energy was transmitted through a $600 \mu \mathrm{m}$ optical
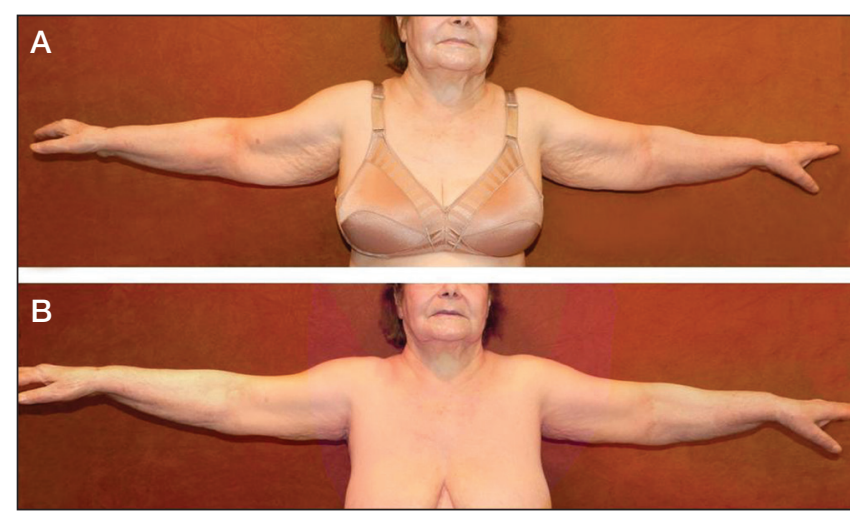

Figure 2) Frontal view of a 58-year-old patient (patient 6 of the series) before (A) and after (B) laser-assisted lypolysis for arm remodelling
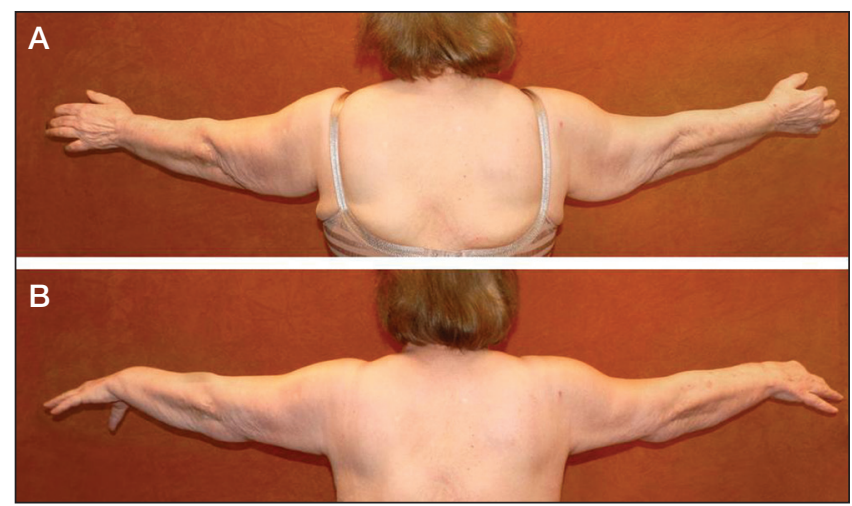

Figure 3) Back view of a 58-year-old patient (patient 6 of the series) before (A) and after (B) laser-assisted lypolysis for arm remodelling

fibre and delivered in a continuous mode with $15 \mathrm{~W}$ power. Total energy was $15 \mathrm{~kJ}$ to $18 \mathrm{~kJ}$ per arm. Previous mathematical modelling suggested that $0.1 \mathrm{~kJ}$ was required to destroy $1 \mathrm{~mL}$ of fat. The parameters were sufficient to achieve $42^{\circ} \mathrm{C}$ when temperature was externally measured in the treatment area using an infrared thermometer (CEM DT-880B, Shenzhen Everbest Machinery Industry Co. Ltd, China). The cannula through which the laser fibre is passed has a blunt tip (Figure 1). During LAL, laser energy is irradiated through lateral fenestrations located at the end of the cannula. This radial modality of laser irradiation differs from standard directional laser irradiation in which the fibre tip extends approximately $2 \mathrm{~mm}$ to $3 \mathrm{~mm}$ out of the cannula. Lower-energy density deposited per area of tissue related to the time of irradiation during cannula movements, drastically decreases the risk of burns to the skin.

\section{Surgical technique}

In all patients, tumescent anesthesia was performed (Klein formula, $0.1 \%$ lidocaine and 1:1,000,000 epinephrine) (17,18). Infiltration ranged from $600 \mathrm{~mL}$ to $800 \mathrm{~mL}$ per arm. All patients received light sedation with midazolam, controlled by the anesthesiologist. Total energy was applied by a crossed-fanning movement of a $2 \mathrm{~mm}$ cannula from various points in the deep and medium-deep planes. All patients received the global energy previously calculated using the mathematical model. Subsequently, the same $2 \mathrm{~mm}$ diameter cannula was used for aspiration with the help of a device at 1 bar $(100 \mathrm{kPa})$ negative pressure (Lipo-MR, Ordisi SA, Barcelona). The cannula has an adaptor located close to the handle to which a tube is fitted for fat aspiration (Figure 1). Additional treatment such as lymphatic drainage, endermology or radiofrequency was not performed. A compression garment (VOE, SA Barcelona, Spain) was prescribed to be used at all times for 15 days. After this time, patients were recommended to use the garment for a further 30 days only at night. 
TABLE 2

Patient demographics and patient arm circumference before and six months after laser-assisted lypolysis

\begin{tabular}{|c|c|c|c|c|c|c|c|c|c|}
\hline \multirow[b]{2}{*}{ Patient } & \multirow[b]{2}{*}{ Age, years } & \multirow[b]{2}{*}{ Body mass index, $\mathrm{kg} / \mathrm{m}^{2}$} & \multirow[b]{2}{*}{ Grade } & \multicolumn{3}{|c|}{ Right arm circumference ${ }^{*}, \mathrm{~cm}$} & \multicolumn{3}{|c|}{ Left arm circumference ${ }^{*}, \mathrm{~cm}$} \\
\hline & & & & Before & After & Difference & Before & After & Difference \\
\hline 5 & 53 & 24.7 & III & 36.4 & 32.2 & 4.2 & 36.3 & 32.5 & 3.8 \\
\hline 9 & 51 & 25.8 & III & 37.4 & 32.2 & 5.2 & 37.7 & 32.3 & 5.4 \\
\hline 12 & 37 & 27.4 & III & 38.3 & 31.6 & 6.7 & 38.2 & 31.4 & 6.8 \\
\hline 13 & 48 & 28.4 & III & 39.7 & 34.9 & 4.8 & 39.3 & 34.6 & 4.7 \\
\hline 15 & 48 & 26.9 & III & 37.6 & 32.3 & 5.3 & 37.8 & 32.4 & 5.4 \\
\hline 16 & 54 & 25.5 & III & 36.2 & 31.6 & 4.6 & 36.1 & 31.7 & 4.4 \\
\hline 18 & 46 & 28.2 & III & 41.4 & 35.2 & 6.2 & 40.7 & 35.8 & 4.9 \\
\hline 19 & 36 & 23.9 & III & 35.2 & 30.7 & 4.5 & 35.3 & 30.6 & 4.7 \\
\hline 20 & 28 & 26.8 & III & 39.9 & 32.4 & 7.5 & 39.6 & 32.2 & 7.4 \\
\hline 22 & 44 & 25.3 & III & 36.7 & 31.1 & 5.6 & 36.4 & 31.4 & 5.0 \\
\hline 4 & 49 & 26,3 & IV & 38.8 & 33.5 & 5,3 & 38.5 & 33.2 & 5.3 \\
\hline 6 & 58 & 25,6 & IV & 37.3 & 32.6 & 4,7 & 37.1 & 32.2 & 4.9 \\
\hline 8 & 41 & 26,7 & IV & 39.6 & 33.1 & 6,5 & 39.7 & 33.4 & 6.3 \\
\hline 10 & 29 & 27,1 & IV & 39.2 & 33.8 & 5,4 & 39.0 & 33.4 & 5.6 \\
\hline 11 & 56 & 23,6 & IV & 37.6 & 34.5 & 3,1 & 37.2 & 34.1 & 3.1 \\
\hline 17 & 58 & 26,4 & IV & 38.1 & 33.5 & 4,6 & 37.8 & 33.6 & 4.2 \\
\hline 21 & 61 & 27,4 & IV & 37.2 & 33.6 & 3,6 & 37.6 & 33.8 & 3.8 \\
\hline Mean & 48.4 & 25.8 & & & & 4.9 & & & 4.86 \\
\hline SD & & & & & & 1.1 & & & 1.1 \\
\hline
\end{tabular}

*Based on Teimourian classification

TABLE 3

\section{Evaluation of the skin characteristics after laser-assisted} lypolysis

\begin{tabular}{ll}
\hline Skin evaluation & Score \\
\hline Tightening & 1 (good skin recovery $\geq 80 \%)$ \\
& $0(<80 \%)$ \\
Firmness & $1($ smooth skin $>80 \%)$ \\
& $0(<80 \%)$ \\
Regularity & 1 (absence of irregularities) \\
& 0 (irregularities) \\
\hline
\end{tabular}

\section{Objective assessment}

For each follow-up, complications were carefully recorded and special attention was devoted to burns, pain and hyperpigmentation. Fever, seromas, severe hematomas, prolonged edema or alterations in sensitivity were also carefully evaluated. Assessment of skin aspects was performed six months postoperatively by an independent evaluator using the following criteria: tightening, firmness and regularity (Table 3). Arm circumference was measured preoperatively and at six months' follow-up.

\section{Subjective assessment}

Patients were asked to rate their level of discomfort during the anesthesia and after the procedure on a questionnaire using a five-point Likerttype scale $(0=$ no pain/discomfort, $1=$ slight pain/discomfort, $2=$ moderate pain/discomfort, $3=$ severe pain/discomfort and $4=$ very severe pain/discomfort); patients were also asked to rate their inability to work $(0=$ no, $1=$ slight, $2=$ moderate, $3=$ severe, and $4=$ very severe) (Table 4). In addition, patients were asked to rate their improvement six months postoperatively (excellent, good, regular, poor) and to score it (from $0 \%$ to $100 \%$ ) on a visual scale (expectations met: $4=$
$90 \%$ to $100 \% ; 3=70 \%$ to $89 \% ; 2=40 \%$ to $69 \%$; and $1=1 \%$ to $39 \%$ ). Patients were asked whether they would recommend the procedure to others. Finally, the overall opinion of both investigators and patients was recorded.

\section{Statistics}

Statistical analysis was performed using SPSS version 22.0 (IBM Coporation, USA). Data are presented as mean \pm SEM. Where applicable, the Student's $t$ test (two sample) was used to calculate P values; $\mathrm{P}<0.05$ was considered to be statistically significant.

Complications

\section{RESULTS}

A total of 22 patients were treated for excessive upper arm fat and ptosis with LAL (Figures 2 to 7). Ecchymoses and prolonged edema were found in 18 and four patients, respectively.

Subjective assessment

Mean pain scores during the anesthesia in groups TIII and TIV were $0.08 \pm 0.28$ and $0.44 \pm 0.73$, respectively $(\mathrm{P}=0.18)$ (Table 5). Mean discomfort scores after the procedure were $0.08 \pm 0.28$ and $0.78 \pm 0.84$ $(\mathrm{P}=0.04)$ for groups TIII and TIV, respectively. Mean down time for groups TIII and TIV was $0.08 \pm 0.28$ days and $0.33 \pm 0.71$ days, respectively $(\mathrm{P}=0.32)$. Of the 22 patients, only nine $(41 \%)$ would recommend this treatment. Overall mean opinion of treatment was poor for both patients and investigators, respectively: $2.77 \pm 0.60$ and $2.54 \pm 0.52$ for group TIII and $3.11 \pm 0.60(\mathrm{P}=0.21)$ and $2.78 \pm 0.67(\mathrm{P}=0.38)$ for group TIV (Table 6).

Objective assessment

Mean arm circumference decreased $5.5 \pm 1.0 \mathrm{~cm}$ in right arm and $5.2 \pm 1.1 \mathrm{~cm}$ in left arm $(\mathrm{P}<0.01)$ in TIII patients and $4.9 \pm 1.1 \mathrm{~cm}$ in right arm and $4.9 \pm 1.1 \mathrm{~cm}$ in left arm $(\mathrm{P}<0.01)$ in TIV patients 

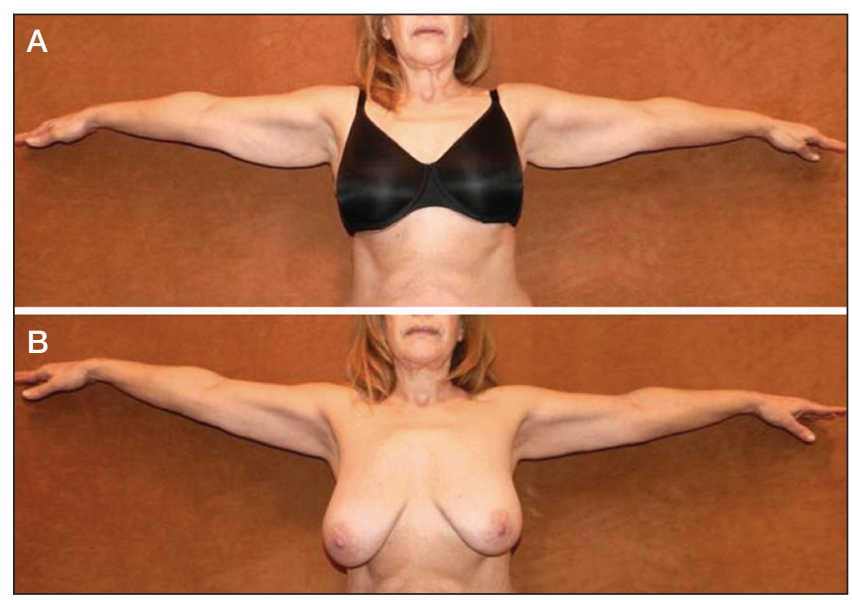

Figure 4) Frontal view of a 54-year-old patient (patient 16 of the series) before (A) and after (B) laser-assisted lypolysis for arm remodelling
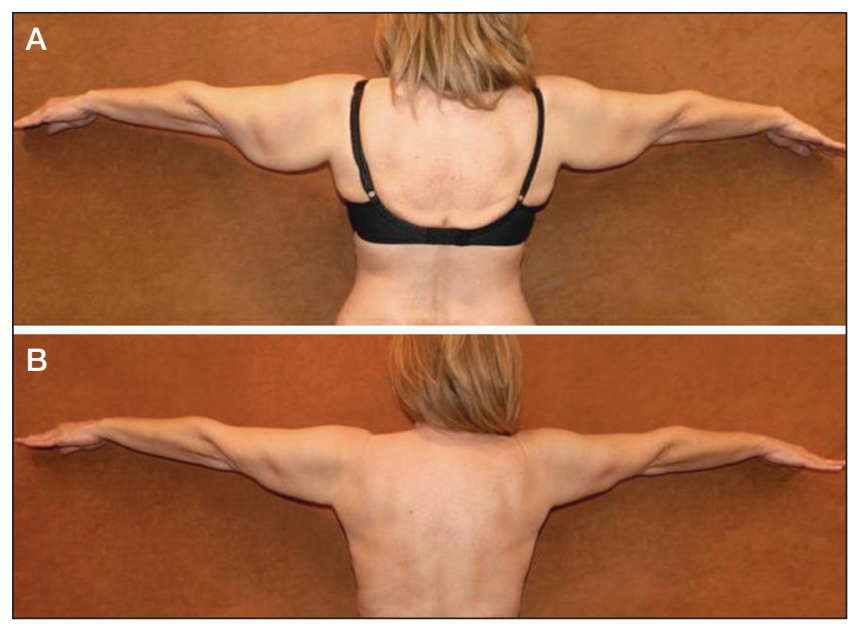

Figure 5) Back view of a 54-year-old patient (patient 16 of the series) before (A) and after (B) laser-assisted lypolysis for arm remodelling

(Table 2). Although the circumference of both arms significantly decreased in both groups, the mean skin tightening, firmness and regularity were 0,0 and 1 , respectively, for group TIII and 0,0 and 1 , respectively, for group TIV. Although mean age was slightly higher in grade IV patients, this was not significant $(\mathrm{P}=0.25)$, as was the case with the higher body mass index in grade III patients $(\mathrm{P}=0.61)$.

\section{DISCUSSION}

In the present study, 22 patients who underwent LAL for Teimourian grades III and IV arm remodelling were prospectively assessed. There were no burns in the entire series. Complications included ecchymoses and prolonged edema in 18 and four patients, respectively. Pain during the anesthesia and discomfort after the procedure were minimal. Despite a decrease in arm circumference in both groups of patients, the skin tightening remained incomplete, which explains the low overall scoring of efficacy from both the investigators and patients.

Teimourian and Malekzadeh (1) devised a classification system of the clinical appearance according to the fat excess and ptosis. As reported in Table 1, El Khatib (19) and Teimourian and Malekzadeh (1) advocated the use of liposuction plus brachioplasty and traditional brachioplasty for Teimourian grades III and IV, respectively. The search for and development of new liposuction technologies and techniques has grown steadily over the past decades to keep pace with patients' requirements and expectations for greater efficacy, safety and minimal scarring. After controversial results, we conducted the present study to objectively assess whether, in cases of high skin laxity and fat excess, treatment with LAL alone would be satisfactory. While many benefits
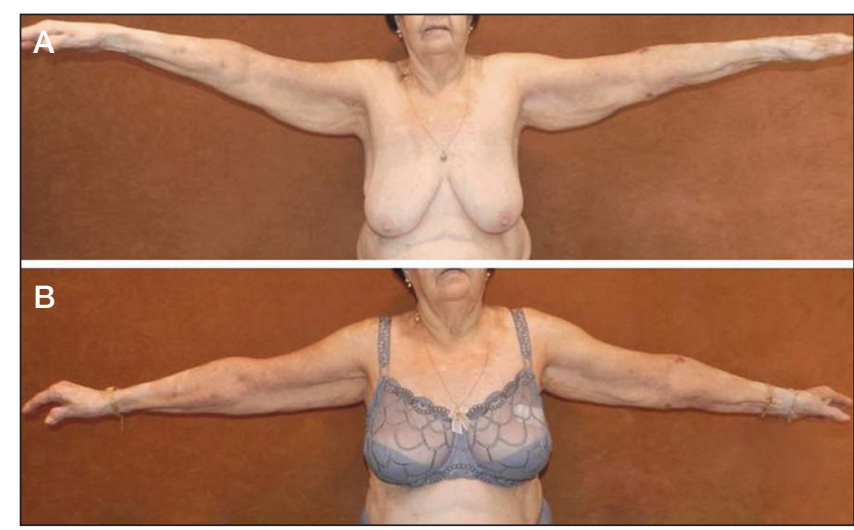

Figure 6) Frontal view of a 61-year-old patient (patient 21 of the series) before (A) and after (B) laser-assisted lypolysis for arm remodelling
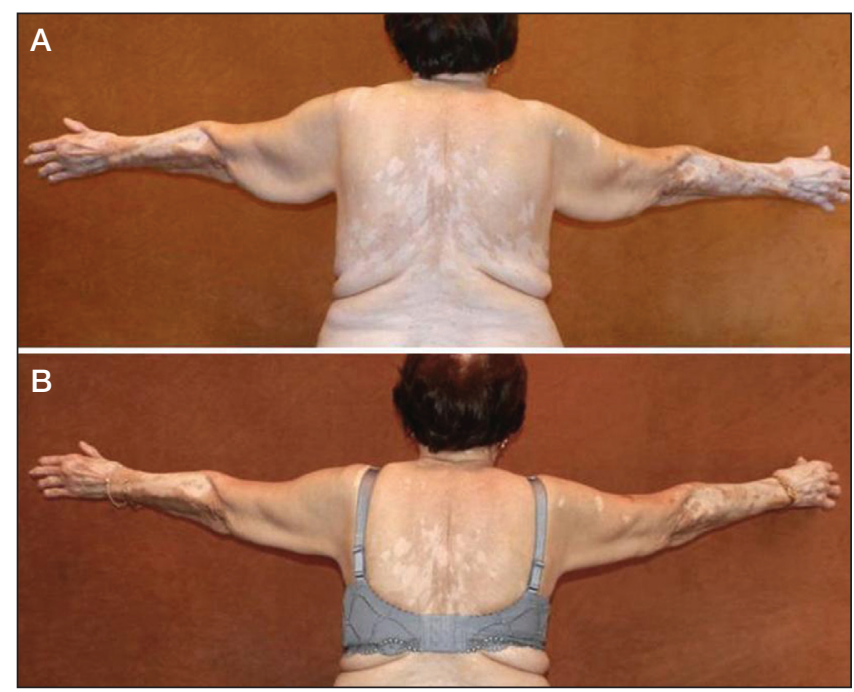

Figure 7) Back view of a 61-year-old patient (patient 21 of the series) before (A) and after (B) laser-assisted lypolysis for arm remodelling

of the LAL technique are described, the parameters used in the present small pilot study did not result in high patient satisfaction. It remains difficult to compare the parameters used in this clinical study with those reported in the literature, because in most of the other studies the cumulative energy used to treat a given volume is usually not reported. Kotlus et al (20) used a neodymium-doped yttrium aluminium garnet laser at $15 \mathrm{~W}, 30 \mathrm{~Hz}$ and a pulse width of $100 \mu$ s. Energy was delivered via a 1.5 $\mathrm{mm}$ cannula housing a $500 \mu \mathrm{m}$ fibre until subcutaneous temperature of $41^{\circ} \mathrm{C}$ was reached. The mean total energy delivered per subject was $13634 \mathrm{~J}$ (range $8524 \mathrm{~J}$ to $21,242 \mathrm{~J}$ ). The mean change in mid arm circumference three months after treatment was $0 \pm 1.8 \mathrm{~cm}$ (range $1.5 \mathrm{~cm}$ to $2 \mathrm{~cm}$ ). No observable improvement was noted in the treated arms in comparison photos at three months according to independent observer evaluation. However, according to our experience, the results must be appreciated after six months. In another study, Dudelzak et al (21) reported a reduction in arm circumference in a series of 20 subjects of whom 10 underwent $1064 \mathrm{~nm}$ laser lipolysis without suction (10). These patients received $7080 \mathrm{~J}$ to $12,026 \mathrm{~J}$ of energy during treatment. They also reported skin retraction and tightening in 16 subjects, but they did not describe how this was measured. Reynaud et al (22) used a $980 \mathrm{~nm}$ diode laser at $6 \mathrm{~W}$. The mean total energy delivered per subject was $12800 \mathrm{~J}$ (range $4700 \mathrm{~J}$ to $17000 \mathrm{~J}$ ). However, the authors did not describe how this was measured. In the present study, similar energy levels were delivered, and arm circumference reduction was observed; however, the skin tightening remained incomplete. This observation supports the fact that selection of the right candidate for LAL is essential. Cases of 
TABLE 4

\section{Post-laser-assisted lypolysis questionnaire}

Tolerance

1. Did you experience pain during anesthesia? No

Yes

Slight

Moderate

Severe

Very severe

2. Did you feel discomfort after the procedure?

No

Yes

$\begin{array}{ll}\text { Slight } & 1 \\ \text { Moderate } & 2 \\ \text { Severe } & 3 \\ \text { Very severe } & 4\end{array}$

3. Has the procedure prevented you from working or interfered with your work? No Yes Slight

Moderate

Severe

Very severe

\section{Efficacy}

a) Has the treatment fulfilled your expectations?

$\begin{array}{lll}\text { Percentage } & 90 \%-100 \% & 1 \\ 70 \%-90 \% & 2 \\ 40 \%-70 \% & 3 \\ 10 \%-40 \% & 4\end{array}$

b) Would you recommend this treatment to others?

$\begin{array}{ll}\text { Yes } & 1 \\ \text { No } & 2\end{array}$

\begin{tabular}{|c|c|c|}
\hline \multicolumn{3}{|c|}{ Overall opinion of the investigator } \\
\hline \multirow[t]{4}{*}{ Efficacy } & Very good & 1 \\
\hline & Good & 2 \\
\hline & Fair & 3 \\
\hline & No change & 4 \\
\hline \multicolumn{3}{|c|}{ Overall opinion of the patient } \\
\hline \multirow[t]{4}{*}{ Efficacy } & Very good & 1 \\
\hline & Good & 2 \\
\hline & Fair & 3 \\
\hline & No change & 4 \\
\hline
\end{tabular}

TABLE 5

Tolerance during anesthesia, discomfort after the procedure and interference with work

\begin{tabular}{|c|c|c|c|c|c|c|}
\hline \multicolumn{4}{|c|}{ Tolerance } & \multirow{2}{*}{\multicolumn{2}{|c|}{$\begin{array}{c}\begin{array}{c}\text { Discomfort } \\
\text { after the } \\
\text { procedure, } \mathbf{n}\end{array} \\
15\end{array}$}} & \multirow{2}{*}{$\begin{array}{c}\begin{array}{l}\text { Interference } \\
\text { with work, } \mathbf{n}\end{array} \\
19\end{array}$} \\
\hline$\overline{\mathrm{NO}}$ & 0 & & & & & \\
\hline \multirow[t]{7}{*}{ YES } & 1 & Slight & Grade III & 1 & 1 & 1 \\
\hline & & & Grade IV & 2 & 3 & 1 \\
\hline & 2 & Moderate & Grade III & 0 & 0 & 0 \\
\hline & & & Grade IV & 1 & 2 & 1 \\
\hline & 3 & Severe & Grade III & 0 & 0 & 0 \\
\hline & & & Grade IV & 0 & 1 & 0 \\
\hline & 4 & Very & 0 & & & \\
\hline
\end{tabular}

advanced upper arm deformities due to excess weight loss of fat surplus or a senile elastosis with skin flaccidity should not be considered for this type of procedure.
TABLE 6

Patients and investigator overall opinion about efficacy of the procedure

\begin{tabular}{llllll}
\hline Overall opinion & & & Patients, $\mathbf{n}$ & Investigator, $\mathbf{n}$ \\
\hline Efficacy & 1 & Very good & & 0 & 0 \\
& 2 & Good & Grade III & 4 & 6 \\
& \multirow{2}{*}{3} & \multirow{2}{*}{ Fair } & Grade IV & 1 & 3 \\
& & Grade III & 8 & 7 \\
& \multirow{2}{*}{4} & \multirow{2}{*}{ No change } & Grade IV & 6 & 5 \\
& & Grade III & 1 & 0 \\
& & Grade IV & 2 & 1 \\
\hline
\end{tabular}

Despite the relatively small number of patients but with a long follow-up period covered in the present study, methodological limitations remain. First, the present study was limited by its nature as a non controlled analysis. Second, no custom dosimetry was used. Although excellent results appear difficult to obtain in high Teimourian grades, it may be possible to improve the outcomes with a more adjusted dosimetry: Cynosure (USA) has developed the SmartSense delivery system (23). This system contains an accelerometer inserted into the intelligent handpiece. The laser power is automatically adjusted by taking into account the setting (high, medium or low) and the motion of the cannula. Similarly, Osyris (France) has developed the LipoControl system. This system integrates a magnetic tracking system to determine the position of magnetic sensors in the cannula. Owing to the tracking system, automatic adjustment of laser power is performed to compensate for cannula movement. Consequently, the laser power varies in step with the speed of the cannula so as to continually deliver the optimal energy. Finally, the decrease in fat was measured indirectly by the arm circumference.

\section{CONCLUSION}

LAL in upper arm remodelling is not sufficient to ensure full skin tightening for Teimourian grades III and IV; complementary surgery is mandatory for grades III and IV to achieve optimal results.

DISCLOSURES: The authors have no financial disclosures or conflicts of interest to declare.

\section{REFERENCES}

1. Teimourian B, Malekzadeh S. Rejuvenation of the upper arm. Plast Reconstr Surg 1998;102:545-51.

2. Richards ME. Minimal-incision brachioplasty: A first-choice option in arm reduction surgery. Aesthet Surg J. 2001;21:301-10.

3. D'Ettorre M, Bracaglia R, Gentileschi S, Tambasco D. S-shaped brachioplasty: An effective technique to correct excess skin and fat of the upper arm. Plast Reconstr Surg 2013;132:675e-676e.

4. Lillis PJ. Liposuction of the arms, calves and ankles. Dermatol Surg 1997;23:1161-8.

5. Duncan DI. Improving outcomes in upper arm liposuction: Adding radiofrequency-assisted liposuction to induce skin contraction. Aesthet Surg J 2012;32:84-95.

6. Zocchi M. Ultrasonic liposculpturing. Aesthetic Plast Surg 1992;16:287-98.

7. Silberg BN. The technique of external ultrasound-assisted lipoplasty. Plast Reconstr Surg 1998;101:552-60.

8. Mordon SR. Wassmer M, Reynaud JP, Zemmouri J. Mathematical modeling of laser lipolysis. Biomed Eng Online 2008;29:7-10.

9. Trelles M, Bonanad E, Moreno-Moraga J, Alcolea J, Mordon S, Leclère FM. Laser-assisted lipolysis for gynecomastia: Safe and effective skin retraction. Rev Col Bras Cir 2013;40:23-31.

10. Leclère FM, Moreno-Moraga J, Mordon S, et al. Laser-assisted lipolysis for cankle remodelling: A prospective study in 30 patients. Lasers Med Sci 2014;29:131-6.

11. Leclère FM, Trelles M, Moreno-Moraga J, Servell P, Unglaub F, Mordon SR. 980-nm laser lipolysis (LAL): About 674 procedures in 359 patients. J Cosmet Laser Ther 2012;14:67-73. 
12. Moreno-Moraga J, Trelles MA, Mordon S, et al. Laser-assisted lipolysis for knee remodelling: A prospective study in 30 patients. J Cosmet Laser Ther 2012;14:59-66.

13. Trelles MA, Mordon SR, Bonanad E, et al. Laser-assisted lipolysis in the treatment of gynecomastia: A prospective study in 28 patients. Lasers Med Sci 2013;28:375-82.

14. Leclère FM, Vogt PM, Moreno-Moraga J, et al. Laser-assisted lipolysis for neck and submental remodeling in Rohrich type IV patients: Fact or fiction? J Cosmet Laser Ther 2014;13:1-6.

15. Leclère FM, Moreno-Moraga J, Alcolea JM, et al. Laser assisted lipolysis for neck and submental remodeling in Rohrich type I to III aging neck: A prospective study in 30 patients. J Cosmet Laser Ther 2014;16:284-9.

16. Leclère FM, Alcolea J, Vogt P, et al. Laser-assisted lipolysis for arm contouring in Teimourian grades I and II: a prospective study of 45 patients. Lasers Med Sci. 2015;30:1053-9.

17. Klein JA. Tumescent technique for regional anesthesia permits lidocaine doses of $35 \mathrm{mg} / \mathrm{kg}$ for liposuction. J Dermatol Surg Oncol 1990;16:248-63.
18. Klein JA. The tumescent technique. Anesthesia and modified liposuction technique. Dermatol Clin 1990;8:425-37.

19. El Khatib HA. Classification of brachial ptosis: Strategy for treatment. Plast Reconstr Surg 2007;119:1337-42.

20. Kotlus BS, Mok C. Patient satisfaction after upper extremity laser lipolysis without suction. Plast Surg Int 2011;2011:352451.

21. Dudelzak J, Hussain M, Goldberg DJ. Laser lipolysis of the arm with and without suction aspiration: clinical and histologic changes. J Cosmet Laser Ther 2009;11:70-3.

22. Reynaud JP, Skibinski M, Wassmer B, Rochon P, Mordon S. Lipolysis using a 980-nm diode laser: A retrospective analysis of 534 procedures. Aesthetic Plast Surg 2009;33:28-36.

23. Mordon S, Plot E. Laser lipolysis versus traditional liposuction for fat removal. Expert Rev Med Devices 2009;6:677-88. 